\title{
Distributing Some, but Not All, Rights of Citizenship According to Ius Sanguinis
}

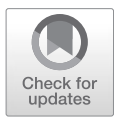

\author{
Ana Tanasoca
}

In an article published in 1987 Joseph Carens famously remarked that '[c] itizenship in Western liberal democracies is the modern equivalent of feudal privilege - an inherited status that greatly enhances one's life chances. Like feudal birthright privileges, restrictive citizenship is hard to justify when one thinks about it closely'. ${ }^{1}$ Some 30 years after, he himself offers a justification of birthright citizenship, a change of heart and mind that he partly explains by the following: 'I thought that my open borders argument was getting at an important truth. At the same time, I recognised that it was not a practical proposal and that it did not provide much guidance for actual policy issues...'; 'In thinking about what to do in a particular situation, we have to consider questions of priority and questions of political feasibility, among other factors. One cannot move always from principles to a plan of action'. ${ }^{2}$ Yet succumbing too much to such feasibility constraints, to use a popular term in the field, is dangerous. Moral (political) theorising should not be too tightly hemmed in by empirical facts. Rather it should be the other way around, insofar as our moral and political theory aims to tell us what existing empirical facts we should strive to change or overcome.

That is why Costica Dumbrava's critique of the ius sanguinis principle of citizenship ascription is, in a way, a much-needed intervention. ${ }^{3}$ While I overall agree with Dumbrava's argument that ius sanguinis is unable to cope with the diversification of family structures and is not that morally appealing to begin with, I disagree with him on the details. I disagree especially with his background assumption that family ties (although not exclusively genetic, as it is presently the case) must play a salient role in the distribution of citizenship - although in the second part of this contribution I do offer a

1 Carens, J. (1987), 'Aliens and citizens: the case for open borders', Review of Politics 49 (2): 251-73.

2 Carens, J. (2013), The Ethics of Immigration. Oxford: Oxford University Press, $\mathrm{x}, 3$.

3 I say 'in a way' because he also relies heavily on empirical facts when arguing against ius sanguinis. 
potential defence of his view against what is probably the strongest objection to his argument, which is that the abolishment of ius sanguinis would split families apart.

The main question is: Why should we insist on ius sanguinis except because it would ensure that nobody is stateless, that is, that everyone's human right to citizenship is satisfied? And insofar as statelessness can be equally avoided via ius soli, why should blood ties create an entitlement to citizenship?

\section{The problem of making citizenship dependent on family ties}

Dumbrava notices that ius sanguinis is unable to cope with the increased diversification of family structures made possible by the assisted reproduction technologies (ART). Yet there are solutions to that problem.

One would be, as Scott Titshaw notices, to reform family laws as to recognise diverse forms of parentage. Another one would be to replace ius sanguinis with ius filiationis, as Rainer Bauböck proposes. If the purpose of upholding ius sanguinis citizenship is to recognise and protect the family, we should replace it with more reliable indicator(s) of parenthood in the case where parenthood is no longer uniquely a matter of biology. As Kerry Abrams argues, the recognition of parenthood now requires 'going beyond the moment of birth'.

Notice, however, were multiple indicators of parenthood to be accepted, those individuals born via ART might be entitled to multiple citizenships. They might, for example, be entitled to the citizenship of the egg donor or the sperm donor or the surrogate mother, as well as to the citizenship of those who intend to raise the child. Such a situation may be deemed problematic in various respects: first because it would create great inequalities; second, because it would end up trivializing citizenship if all types of parenthood (e.g., the relationships the surrogate mother, the egg donor or the sperm donor, and the intended parents have with the child) were to be treated as equally morally relevant and therefore worthy of state recognition.

Dumbrava also bemoans ius sanguinis as failing to capture the political function of citizenship. If we grant citizenship to the children of citizens because we expect such children to develop the attitudes and skills required for political participation in their parents' state, why not wait to confer citizenship until these attitudes and skills are actually confirmed? And what if they never developed these skills and attitudes? Should people be deprived of their birthright citizenship altogether, or perhaps only of their political 
rights? Besides, while we might have a clear idea of what skills (e.g., reading and writing to enable voting) citizenship requires, what can we say of the attitudes citizens should display? Should apathetic voters be stripped of their political rights for failing to display the right attitude towards their right to vote? According to Dumbrava's reasoning, perhaps they should.

But the main problem both with Dumbrava's critique and the other contributors' accounts is that they conceive of citizenship as primarily reflecting a bond (genetic or affective or intentional) between two individuals - the parent and the child - and not as a bond between an individual and a state, or an individual and a political community. Such accounts overlook the political nature and function of citizenship and are also likely to leave us with a very limited, rigid, and exclusionary conception of the demos, one that is at the same time unjust and inefficient. As Rainer Bauböck put it elsewhere, '[n]ormative principles for membership must instead lead to boundaries that avoid both under- und over- inclusiveness' ${ }^{4}$ particularly in the context of increased global mobility.

In his contribution to this Forum, however, Bauböck argues that birthright citizenship creates a 'quasi-natural equality of status' among those entitled to it. He represents it as avoiding divisions, by making citizenship part of people's unchosen and permanent personal features, namely, where and to whom one is born. ${ }^{5}$ Yet as such birthright creates exclusion and inequality between those entitled and those unentitled that can be hard to justify or overcome, as Lois Harder rightly notices. Why should the son of a citizen of state $A$ be entitled to citizenship in that state, but not a regular immigrant residing for years in state $A$, paying taxes there and having virtually all of his interests deeply affected by the institutions of state $A$ ? While the first has unconditional and automatic access to citizenship - a right to citizenship in virtue of his blood ties to another citizen - the second has to apply for naturalisation, which is subject to the state's discretionary powers. That is, his residence in that state, contributions to the community, or his interests being affected by that state's institutions do not automatically ground any right to citizenship for him in the same way blood ties do for the citizens' progeny.

4 Bauböck, R. (2015), 'Morphing the demos into its right shape. Normative principles for enfranchising resident aliens and expatriate citizens', Democratization 22 (5): 820-39.

5 This last bit is problematic in itself. Tying citizenship - that has an immense influence on individuals' life opportunities and welfare - to underserved and permanent personal features like ancestry is after all morally problematic even if practically convenient for states. 
Why should the boundaries of the demos be defined by family ties, rather than by social or political kinship? By ascribing citizenship on the basis of blood ties we conceive of political communities as big extended families rather than communities gathered around common interests, values, and goals. Such a conception of the demos is disrespectful of individual consent (no one consents to being born, to having these parents rather than others, or to the colour of their passport). It attaches too much value to contingencies and too little value to individual choices. A political community based on ancestry is, after all, just an overinflated dynasty.

\section{Limiting the scope of ius sanguinis}

While abolishing ius sanguinis might be a good idea, we could nonetheless be worried that the transition costs would outweigh potential benefits. After all, most families today are still founded on blood ties. Abolishing ius sanguinis altogether could create situations where parents and children are not citizens of the same state. Such policy, it is argued by several contributors, would have the disruptive effect of potentially separating families, preventing parents from discharging their parental duties, and leaving children deprived of the care they are entitled to. (Of course, nothing prevents parents from applying for a visa or for citizenship if they wish to reside or share a citizenship with their progeny; but let us assume that the parents do not have the means to do that, or that even doing that would not guarantee that they can be reunited with their child immediately as we would wish.) This is, I think, the strongest argument against Dumbrava's proposal.

One solution would be, of course, to replace ius sanguinis with another principle for citizenship allocation, perhaps affected interests or perhaps ius domicilii. As children's and parents' interests are interdependent, the affected interests principle would ensure that children and parents are members of the same state. So would ius domicilii, at least in cases where parents and children are currently domiciled in the same state (although it would provide no citizenship-based grounds for family reunion, in cases where they are not).

My proposal, however, takes a different tack. Notice that in a world with genuinely open borders we need not be worried that parents and children would be separated if they are citizens of different states. The solution I propose would therefore be to limit the scope of ius sanguinis - that is distribute some, but not all rights traditionally associated with citizenship, on the basis of ius sanguinis. This would be an appealing compromise, insofar as some of us may think citizenship should not be distributed on the basis of 
blood ties, while nonetheless accepting that blood ties are one (albeit not the only) relevant ground for the distribution of some categories of rights.

As Bauböck notices in his contribution, immigrant minors who are EU citizens have a 'right to stay' that protects their primary caregivers from deportation. Yet, most likely, this policy is a recognition of an entitlement to care that the child has - not a recognition of a right the parents have to stay strictly in virtue of their blood ties to the child. Blood ties may simply serve as the operational indicator of the primary caregivers.

My preferred solution, however, would entitle a person to the limited enjoyment of some rights in a state, on the basis of having blood ties to someone who is already a citizen of that state. I primarily have in view, among that limited subset of rights, the right to enter and leave the state and the right of residence. By 'limited' I also mean that the enjoyment of these rights, purely on the basis of ius sanguinis, should be time-constrained. ${ }^{6}$

Take the case of minors having a different citizenship from their parents. My proposal would be: either the parents should be granted extensive residence rights, until the minor reaches adulthood as in the case above; or else the minor should be granted these rights, provided the parents wish to remain in their country of citizenship. Consider the case of a couple, both citizens of state $A$, who move to state $B$ and give birth there to a child, who becomes via ius soli citizen of $B$. Under my proposal, the parents would be automatically entitled to residence in state $B$ until the child is 18 , provided the family decides to reside in state $B$; equally, the child would be automatically entitled to reside in state $A$ until 18 if the family decides to reside there.

Things would be different in the case of adults. Say my mother and I are citizens of different countries, she of state $A$ and I of state $B$. Under my proposal, I as an adult would not be entitled to all the current rights of citizenship in state $A$ on the basis of ius sanguinis. Still, I may nonetheless be automatically entitled on the same ground to a right to freely enter state $A$ and reside there for a limited period of time (for example, 1 month). That would allow me to visit and spend time with my mother, preserving my family ties intact and allowing me to discharge whatever ordinary duties I have towards family members. But what if my mother becomes frail or ill,

6 In the same vein, Iseult Honohan proposes in her contribution to this debate that minors born in another states other than that of their parents should also be entitled to their parents' citizenship but only until they reach adulthood; from then on, they can lose this citizenship if they do not continue residing in the country of parental citizenship. This would be another way of limiting ius sanguinis entitlements. 
and I become her main caregiver and thus need to spend more than one month in state $A$ ? If the circumstances require it, I should be able to petition for my right to remain to be extended, and that petition should be automatically granted so long as authorities are satisfied that the requisite circumstances really do prevail. The period for which one can enjoy such rights, and the categories of rights one enjoys, might be extendable in this way. Alternatively, of course, I could bring my mother to reside with me in state $B$ on a (elderly) dependent visa.

Under my proposal, there would thus be a limit to what one is entitled to under ius sanguinis alone. We should not think of the distribution of citizenship rights as an all-or-nothing affair. Among the many component rights currently associated with citizenship, different rights can and should be distributed separately according to different criteria. By the same token, many different criteria can serve as a legitimate ground for the distribution of any one of those constituent rights.

Open Access This chapter is licensed under the terms of the Creative Commons Attribution 4.0 International License (http://creativecommons.org/licenses/by/4.0/), which permits use, sharing, adaptation, distribution and reproduction in any medium or format, as long as you give appropriate credit to the original author(s) and the source, provide a link to the Creative Commons license and indicate if changes were made.

The images or other third party material in this chapter are included in the chapter's Creative Commons license, unless indicated otherwise in a credit line to the material. If material is not included in the chapter's Creative Commons license and your intended use is not permitted by statutory regulation or exceeds the permitted use, you will need to obtain permission directly from the copyright holder.

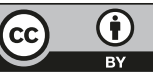

